\title{
"Isso não é um livro de história": Michel Foucault e a publicação de documentos de arquivos
}

\author{
Marlon Salomon* \\ Universidade Federal de Goiás, Goiânia, Goiás, Brasil
}

\section{RESUMO}

Entre 1973 e 1982, Michel Foucault dedicou-se à publicação de documentos de arquivo. Em 1973, publicou o memorial de Rivière; em 1977, os extratos do livro de um libertino inglês; em 1978, as lembranças de uma jovem hermafrodita; e em 1982 uma seleta de documentos judiciários. Dividido em duas partes, este artigo busca compreender o que esteve em jogo nesse gesto arquivístico-editorial. Na primeira parte, analisarei as relaçóes existentes entre os textos que compóem esse corpus e como se inserem no quadro, então, de suas pesquisas. Depois, estudarei os deslocamentos existentes entre o projeto de publicação de uma coletânea de arquivos da infâmia e a publicaçáo do livro com documentos da Bastilha. Na segunda parte, apresentarei duas hipóteses sobre os problemas ligados a esse projeto editorial: 1) Mostrarei que se tratava de um estudo das condiçôes extraliterárias da constituição da literatura como saber; 2) Mostrarei como seu empenho em publicar documentos não pretendia apenas dar a palavra aos sem-história, mas assinalar que havia um pensamento em suas falas. Esse empenho chocava-se com um dos principais dogmas historiográficos contemporâneos.

Palavras-chave: historiografia francesa; teoria da história; arquivologia; biblioteconomia; saberes literários.

\section{"It is not a history book": Michel Foucault and the publication of archival documents}

\section{ABSTRACT}

Between 1973 and 1982, M. Foucault dedicated himself to editing and publishing archival texts. He published Pierre Rivière's memorial in 1972, extracts from an English libertine's book in 1978, and the memoirs of a young hermaphrodite in 1979. In 1982, he published a selection of documents from court archives. This article, organized in two parts, aims to understand what was at play in that archivistic-editorial endeavor. In the first part, I analyze the relations among the texts that make up that corpus and their insertion in Foucault's overall

DOI: http://dx.doi.org/10.1590/2237-101X020040011

Artigo recebido em 18 de abril de 2018 e aceito para publicação em 29 de junho de 2018.

* Professor da Universidade Federal de Goiás/Faculdade de História, Programa de Pós-graduação em História, Goiânia/GO. Pesquisador do CNPq - Brasil. E-mail: marlonsalomon@gmail.com. https://orcid. org/0000-0002-2446-2141. 
research work of that period. Then, I address the contrasts between the project to publish a collection of archives of infamy, as it was announced in 1977, and the book actually published in 1982 with documents of the Bastille. In the second part, I put forward two hypotheses I consider to be connected to that editorial project: 1) it was a study of extra-literary conditions of the constitution of literature as knowledge; and 2) his effort to publish archival documents sought not only to "give voice" to those with no history, but also to show that a thought was embedded in their pronouncements. Foucault's performance swam against the main currents of historiographical dogmas at the time.

Keywords: French historiography; theory of history; archive science; library science; literary knowledge forms.

\section{"Eso no es un libro de historia": Michel Foucault y la publicación de documentos de archivos}

\section{RESUMEN}

Entre 1973 y 1982, M. Foucault se dedicó a la publicación de documentos de archivo. En 1973, publicó el memorial de Rivière, en 1977, los extractos del libro de un libertino inglés; en 1978, los recuerdos de una joven hermafrodita; y en 1982, una selecta de documentos judiciarios. Divido en dos partes, este artículo busca comprender lo que estuvo en juego en ese gesto archivístico-editorial. En la primera parte, analizaré las relaciones existentes entre los textos que componen ese corpus y cómo se insieren en el cuadro, entonces, de sus investigaciones. Después, estudiaré los dislocamientos existentes entre el proyecto de publicación de una antología de archivos de la infamia y la publicación del libro con documentos de la Bastilla. En la segunda parte, presentaré dos hipótesis sobre los problemas ligados a ese proyecto editorial: 1) mostraré que se trataba de un estudio de las condiciones extraliterarias de la constitución de la literatura como saber; 2) expondré cómo su empeño en publicar documentos no pretendía apenas dar la palabra a los sin-historia, sino marcar que también había un pensamiento en sus hablas. Ese empeño chocó con uno de los principales dogmas historiográficos contemporáneos.

Palabras clave: historiografía francesa; teoría de la historia; archivología; biblioteconomía; saberes literarios. 
"ISSO NÂO É UM LIVRO DE HISTÓRIA": MICHEL FOUCAULT

E A PUBLICAÇÃO DE DOCUMENTOS DE ARQUIVOS

Marlon Salomon

\section{Apresentaçáo}

Do alvorecer dos anos 1970 ao início da década seguinte, uma prática particularmente inusitada marcou o trabalho filosófico de Michel Foucault: a edição e publicação de textos e documentos de arquivos. Textos inéditos, parcialmente publicados, totalmente desconhecidos, inacessíveis em língua francesa ou apenas acessíveis aos poucos pesquisadores interessados pela velha papelada da história. Em 1973, Foucault publicou o memorial de Pierre Rivière, um camponês parricida que havia degolado sua mãe, sua irmã e seu irmão, em um volume ao qual acresceu as peças judiciárias que compunham o caso e artigos da imprensa a seu respeito. Em 1977, Foucault fez traduzir e publicar extratos do livro do libertino inglês autor de My Secret Life. No ano seguinte, editou o volume que reunia "as lembranças" de Herculine Barbin dite Alexina B. e um pequeno dossiê com alguns documentos relativos ao estranho destino dessa hermafrodita do século XIX. Finalmente, em 1982, com Arlette Farge, publicou Le désordre des familles. Lettres de cachet des Archives de la Bastille - o livro provavelmente menos lido, citado e conhecido de Foucault.

O objetivo deste artigo é compreender o que esteve em jogo nesse gesto arquivístico-editorial. Num primeiro momento, buscarei analisar as relaçóes que se podem traçar internamente entre os textos que constituem esse corpus e de que maneira eles se inserem no quadro mais amplo de suas preocupaçóes e pesquisas daquele período. Em seguida, estudarei os deslocamentos que se podem identificar entre o projeto de publicação das lettres de cachet, de 1977, e o livro de 1982 propriamente dito. Na segunda parte do artigo, tentarei apresentar duas hipóteses sobre os problemas que me parecem indissociavelmente ligados a esse "projeto" do filósofo francês: de um lado, procurarei indicar que se tratava de um estudo das condições extraliterárias da constituição de um saber como a literatura feito a partir de uma análise de escritos que vagam em seu exterior; de outro, buscarei mostrar como seu esforço de publicar textos anônimos e documentos de arquivo em sua aridez, sem comentários ou interpretaçóes, não pretendia apenas "dar a palavra" aos sem-história, mas mostrar como havia um pensamento nessas falas obscuras e quase ininteligíveis; esse esforço, intentarei apresentá-lo, chocava-se com um dos principais dogmas do moderno pensamento histórico. Veremos por que ele insistia no fato de que um livro voltado a exumar e publicar documentos de arquivo, paradoxalmente, não era um livro de história.

\section{Editar arquivos, um gesto filosófico}

O volume sobre Rivière ${ }^{1}$ é sem dúvida o mais famoso desses quatro textos. Resultou de um projeto coletivo (que reunia historiadores, filósofos e sociólogos) realizado ao longo de dois anos no espaço que inaugurou o "seminário" do recém-eleito professor do Collège de

\footnotetext{
${ }^{1}$ FOUCAULT, Michel [1973]. Eu, Pierre Rivière, que degolei minha mãe, minha irmã e meu irmão... 2. ed. Tradução de Denise Lezan de Almeida. Rio de Janeiro: Graal, 2013.
} 
"ISSO NÃO É UM LIVRO DE HISTÓRIA": MiChEL FOUCAUlT E A PUBLICAÇÁO DE DOCUMENTOS DE ARQUIVOS

\section{Marlon Salomon}

France em 1971. My Secret Life é uma versão condensada do título original em 11 volumes no qual, ao longo de milhares de páginas, um cavalheiro anônimo inglês relata a crônica de suas aventuras e da exploração de sua compulsiva sexualidade. Foucault acresceu-lhe um prefácio de três páginas. ${ }^{2} \mathrm{O}$ volume sobre Herculine Barbin foi publicado em 1978 em uma coleção, então criada pela Gallimard, dirigida por Foucault e intitulada "As Vidas Paralelas”. Esse volume é fundamentalmente formado por documentos e há apenas duas páginas de próprio punho do filósofo francês, em que ele comenta o estado da documentação sobre Barbin e anuncia que um volume da História da sexualidade seria consagrado aos hermafroditas. ${ }^{3}$ Le désordre des familles é um livro dedicado a exumar e publicar as lettres de cachet, ordens de prisão expedidas com selo real e pertencentes aos arquivos da Bastilha. ${ }^{4}$

Numa olhadela, é difícil deixar de perceber certa coerência no conjunto dessas publicaçôes, que poderíamos agrupar em torno desse gesto estranhamente filosófico de edição e publicação de textos não filosóficos de anônimos desconhecidos. Todavia, não era a primeira vez que Foucault envolvia-se em um trabalho dessa natureza. ${ }^{5}$ Alguns anos antes, coube a ele e a Gilles Deleuze supervisionar a edição francesa das obras completas de Friedrich Nietzsche. Preparadas por Giorgio Colli e Mazzino Montinari, fundadas em pesquisas originais nos arquivos de Weimar, tratava-se de restituir a edição das obras do filósofo alemão e corrigir as deformaçóes nelas introduzidas por Elisabeth Nietzsche e Peter Gast, particularmente em relação às ediçóes do Nachlass, que durante muito tempo se identificou ao projeto de um livro que intitular-se-ia A vontade de potência. Em 1967, o primeiro tomo dessa edição (que viria a ser o quinto volume dessas Werke) seria publicado com uma "Introdução geral" assinada por Foucault e Deleuze. Não quero com isso ladear o filósofo alemão com o criminoso, o libertino desconhecido, a hermafrodita e os homens obscuros e infames - mesmo que, nessa "Introdução", Foucault e Deleuze o inscrevessem entre "os pensadores malditos". ${ }^{6}$ Não se trata de aproximá-los de um autor largamente reconhecido e pertencente à história da filosofia, mas de lembrar esse precedente editorial e sublinhar duas diferenças: neste caso, Foucault foi chamado para supervisionar um projeto de publicação em língua francesa do qual ele não era o formulador. Logo, há aí um precedente, mas não uma continuidade. Além disso, ao contrário dos obscuros desviantes, Nietzsche era um autor e possuía um opus.

\footnotetext{
${ }^{2}$ ANÔNIMO. My secret life. Récits de la vie sexuelle d'un anglais de l'époque victorienne [extraits]. Paris: Les Formes du Secret, 1977.

${ }^{3}$ FOUCAULT, Michel (Org.). Herculine Barbin dite Alexina B. Paris: Gallimard, 1978.

${ }^{4}$ FOUCAULT, Michel; FARGE, Arlette. Le désordre des familles. Lettres de cachet des Archives de la Bastille. Paris: Gallimard/Julliard, 1982.

${ }^{5}$ E não seria a última. Em 1983, com Paul Veyne e François Wahl, ele lançaria uma nova coleção nas edições do Seuil intitulada "Des travaux”. Cf. FOUCAULT, Michel [1983]. Des travaux. In: Dits et écrits. 2. ed. Paris: Gallimard, 2001, p. 1185-1186, v. II [Texto no 324].

${ }^{6}$ FOUCAULT, Michel; DELEUZE, Gilles. [1967]. Introduction générale. In: FOUCAULT, Michel. Dits et écrits, op. cit., p. 589-592, v. I [Texto no 45].
} 
“ISSO NÂO É UM LIVRO DE HISTÓRIA": MiChel FoUCAULT E A PUBLICAÇÃO DE DOCUMENTOS DE ARQUIVOS

\section{Marlon Salomon}

\section{Um corpus}

Poderíamos, todavia, pensar internamente esse corpus. Os três primeiros volumes sugerem certa proximidade imediata e nos remetem a preocupaçóes que marcaram o seu editor durante aquele período. As memórias de Rivière punham em questão os discursos psiquiátricos, psicológicos, psicanalíticos e criminológicos sobre a delinquência. ${ }^{7}$ A crítica aos discursos psi, sem dúvida, prolongarse-ia em seguida. Em 1976, no primeiro volume de sua História da sexualidade, Foucault havia se utilizado de My Secret Life. Para ele, seu autor desconhecido se inscrevia nesse "grande processo de colocaçáo do sexo em discurso", nessa "injunçáo plurissecular de falar do sexo". Segundo o filósofo francês, nisso residia sua essência: "que o homem ocidental há três séculos tenha permanecido atado a essa tarefa que consiste em dizer tudo sobre seu sexo". Daí exatamente o título do tópico que abria o primeiro capítulo do livro, "A incitação aos discursos", com o qual ele pretendia precisamente questionar a hipótese (denominada de repressiva) segundo a qual, após séculos de autenticidade, o sexo teria sido reprimido a partir da era vitoriana. No final desse ano de 1976, Foucault publicou no Le Monde um longo artigo intitulado "O Ocidente e a verdade do sexo" dedicado ao livro do gentleman britânico e no qual ele insistia: "Ao invés de uma sociedade dedicada à repressão do sexo, eu veria a nossa dedicada à sua 'expressão." ${ }^{10}$ Não apenas a exprimi-lo, mas a extrair dele a verdade. Nossa relaçáo com o sexo residiria nessa vontade de saber, "a tal ponto imperiosa, (...) que chegamos não somente a procurar a verdade do sexo, mas a solicitar-lhe nossa própria verdade". ${ }^{11}$

É rigorosamente aí que podemos situar seu interesse pelo caso de Barbin. É o que atesta o texto da introdução à edição americana de suas memórias, cuja versão em francês seria publicada no mesmo ano de 1980 sob o título "O verdadeiro sexo". Durante muito tempo, nas sociedades ocidentais, desconheceu-se a exigência de se atribuir um verdadeiro sexo aos indivíduos. Assim, do ponto de vista jurídico e médico, simplesmente admitia-se que os hermafroditas possuíssem os dois. Durante a Idade Média, cabia ao pai e ao padrinho escolher, no momento do batismo, o sexo que ele manteria. Mais tarde, no limiar da idade adulta e nupcial, o hermafrodita poderia livremente decidir se manteria o sexo que se lhe atribuiu ou se preferia o outro, sob a condição de não mais mudá-lo. Segundo Foucault, a partir do século XVIII,

as teorias biológicas da sexualidade, as condiçóes jurídicas do indivíduo, as formas de controle administrativo nos Estados modernos conduziram pouco a pouco à recusa da ideia de uma

\footnotetext{
${ }^{7}$ FOUCAULT, Michel [1976]. Entretien avec Michel Foucault. In: Dits et écrits, op. cit., p. 97, v. II [Texto $\mathrm{n}^{\mathrm{o}}$ 180].

${ }^{8}$ FOUCAULT, Michel [1976]. História da sexualidade. A vontade de saber. 18. ed. Tradução de Maria Thereza Albuquerque e J. A. Guilhon Albuquerque. Rio de Janeiro: Graal, 2007, p. 28.

${ }^{9}$ Ibidem, p. 29.

10 "Plutôt qu’une société vouée à la répression du sexe, je verrais la nôtre vouée à son 'expression'." FOUCAULT, Michel [1976]. L’Occident et la vérité du sexe. In: Dits et écrits, op. cit., p. 103, v. II [Texto no 181]. 11 "À ce point impérieuse, (...) que nous en sommes arrivés non seulement à chercher la vérité du sexe, mais à lui demander notre propre vérité.” Idem, p. 103.
} 
“ISSO NÃo É UM LIVRO DE HISTÓRIA": MiChEL FOUCAULT

E A PUBLICAÇÁO DE DOCUMENTOS DE ARQUIVOS

Marlon Salomon

mistura dos dois sexos em um só corpo e a restringir por consequência a livre escolha dos indivíduos incertos. Doravante, a cada um, um sexo, e apenas um. A cada um sua identidade sexual primeira, profunda, determinada e determinante. ${ }^{12}$

As memórias de Barbin, que havia sido obrigada a mudar legalmente de sexo e a modificar sua identidade civil após um processo judiciário, e que, incapaz de adaptar-se à sua nova identidade, acabaria por suicidar-se, eram um documento desta "estranha história do "verdadeiro sexo"”. ${ }^{13}$ Ela "foi um desses heróis desafortunados da caça à identidade". ${ }^{14} \mathrm{E}$ se a psicanálise enraizou seu vigor cultural em nossas sociedades, é porque, para Foucault, "ela nos promete ao mesmo tempo o nosso sexo, o verdadeiro, e toda essa verdade de nós mesmos que reside secretamente nele". ${ }^{15}$ Isso nos permite observar a posição estratégica dessa exigência arquivística e desse gesto editorial no trabalho do filósofo francês nos anos 1970. A edição desses textos permitia captar, como ele afirmava, "o poder de perturbação próprio" desse tipo de discurso "e o conjunto de táticas pelas quais se tenta recobri-lo, inseri-lo e classificá-lo como um discurso de um louco ou de um criminoso"16 ou de um anormal.

Vemos como essas entrevistas, artigos e prefácios, todos mais ou menos da mesma época, relacionam-se diretamente com a edição desses documentos e ressoam seu interesse por sua publicação. Todavia, há um texto do início de 1977 que explicita bem o interesse por esse trabalho. Refiro-me ao $A$ vida dos homens infames. ${ }^{17}$ Esse texto deveria ser a introdução de uma antologia de lettres de cachet, cujo projeto, no ano seguinte, tornar-se-ia a coleção "As Vidas Paralelas". Logo, não há uma linha reta unindo esses textos entre si. Entre 1973 e 1977, Foucault dedicou-se fundamentalmente às pesquisas que o conduziram à publicação de Vigiar e punir, em 1975, e $A$ vontade de saber, no ano seguinte. Concluído o primeiro volume da História da sexualidade, Foucault parece voltar-se imediatamente ao mesmo tipo de projeto inaugurado por Pierre Rivière (A vida dos homens infames e Vida secreta são de 1977 e Herculine Barbin de 1978). Antes de pensá-lo em conjunto com os três livros anteriormente editados, poderíamos relacioná-lo a Le désordre des familles.

\footnotetext{
12 "Les théories biologiques de la sexualité, les conditions juridiques de l'individu, les formes de contrôle administratif dans les États modernes ont conduit peu à peu à refuser l'idée d'un mélange des deux sexes en un seul corps et à restreindre par conséquent le libre choix des individus incertains. Désormais, à chacun, un sexe, et un seul. À chacun son identité sexuelle première, profonde, déterminée et determinante." FOUCAULT, Michel [1980]. Le vrai sexe. In: Dits et écrits, op. cit., p. 935-936, v. II [Texto no 287].

13 "Étrange histoire du 'vrai sexe". Ibidem, p. 937.

14 "À été l'un de ces héros malheureux de la chasse à l'identité". Ibidem, p. 938.

15 "Elle nous promet à la fois notre sexe, le vrai, et toute cette vérité de nous-mêmes qui veille secrètement en lui". Ibidem, p. 937.

${ }^{16}$ FOUCAULT, Michel [1973]. Eu, Pierre Rivière, que degolei minha mãe, minha irmã e meu irmão..., op. cit., p. 14.

${ }^{17}$ FOUCAULT, Michel [1977]. La vie des hommes infâmes. In: Dits et écrits, op. cit., p. 237-253, v.

II [Texto no 198].
} 
"ISSO NÂO É UM LIVRO DE HISTÓRIA": MiChEl FOUCAUlT E A PUBLICAÇÁO DE DOCUMENTOS DE ARQUIVOS

\section{Marlon Salomon}

\section{As lettres de cachet}

As lettres de cachet não haviam sido descobertas por Foucault nesse contexto. Ele costumava dizer que fez contato com elas quando havia estudado "os procedimentos de internação administrativa a partir do século XVII até a Revolução". ${ }^{18}$ De fato, em sua tese de doutorado, ele refere-se a elas em mais de uma passagem. Elas aparecem logo no início do capítulo sobre "A grande internação". ${ }^{19}$ Entretanto, há que se observar que, ao longo de todo livro, Foucault náo se utiliza em momento algum dos arquivos das lettres propriamente ditos. Quando não se refere às estatísticas sobre o número de indivíduos encarcerados por meio desse expediente, ${ }^{20}$ trata delas como um mecanismo de poder, como emergência de uma nova "sensibilidade" em torno da família e da qual o poder monárquico seria solidário, ${ }^{21}$ mas sobretudo das normas, regulamentos e declaraçóes do final do século XVIII que, de certa forma, limitaram sua utilização, particularmente a famosa Circular de Breteuil. ${ }^{22}$ Logo, ele estava mais preocupado em destacar o que o crepúsculo dessa prática de enclausuramento representava no quadro da grande internaçáo do que em traçar sua genealogia ou debruçar-se internamente sobre esse acervo.

Já em seu estudo sobre $O$ nascimento da prisão, ele se refere a elas em pelo menos quatro ocasiôes. No início do subcapítulo intitulado "A mitigação das penas", Foucault sustenta a tese de que para que a prisão substituísse o suplício na história da punição, era preciso que seu estatuto jurídico se transformasse, visto que na França, ao menos, ela era fortemente desqualificada por estar associada, por meio das lettres de cachet, ao talante e aos excessos do poder absolutista, justaposta, portanto, à justiça regular. ${ }^{23}$ Já no subcapítulo sobre "O panoptismo", ele insiste no fato de que as lettres de cachet não poderiam ser vistas tão somente como símbolo do líbito monárquico. Durante o século XVIII, o controle policial não é unidirecional; ele se encontra nas mãos do rei, sem dúvida; mas ele também responde "às solicitaçôes de baixo", fundamentalmente ligadas ao "internamento de toda uma infrapenalidade": desordem, agitação, desobediência, mau comportamento. Foucault sugere que, dessa forma, ao instrumento de controle político que exerce a polícia, acrescenta-se uma complexa função disciplinar. ${ }^{24}$

\footnotetext{
18 "Les procédures de l'enfermement administratif depuis le XVIIè siècle jusqu'à la Révolution." FOUCAULT, Michel; FARGE, Arlette. Le désordre des familles. Lettres de cachet des Archives de la Bastille, op. cit., p. 9. ${ }^{19}$ FOUCAULT, Michel. Histoire de la folie à l'âge classique. 2. ed. Paris: Gallimard, 1972, p. 59 [Tradução brasileira: FOUCAULT, Michel. História da loucura na Idade Clássica. 5. ed. São Paulo: Perspectiva, 1997, p. 48].

${ }^{20}$ Ibidem, p. 135 [Ibidem, p. 95].

${ }^{21}$ Ibidem, p. 145 [Ibidem, p. 104-105].

${ }^{22}$ FOUCAULT, Michel. História da loucura na Idade Clássica, op. cit., p. 143, 403, 440 e 466.

${ }^{23}$ FOUCAULT, Michel. Surveiller et punir. Naissance de la prison. Paris: Gallimard, 1975, p. 121-122 [Tradução brasileira: FOUCAULT, Michel. Vigiar e punir. História da violência nas prisôes. 9. ed. Tradução de Raquel Ramalhete. Petrópolis: Vozes, 1991, p. 106-107].

${ }^{24}$ Ibidem, p. 214, 216 [Ibidem, p. 187, 188]. A história da tradução no Brasil do termo lettre de cachet parece justificar o relativo silêncio que recai sobre elas nas análises do trabalho do filósofo francês. A tradução bra-
} 
"ISSO NÂO É UM LIVRO DE HISTÓRIA": MiChEl FOUCAUlT E A PUBLICAÇÁO DE DOCUMENTOS DE ARQUIVOS

Marlon Salomon

Assim, vemos que se Foucault conhecia-as desde a época de suas pesquisas para sua tese de doutorado, não se pode afirmar que ele as houvesse então utilizado. Já em 1975, ao inseri-las nos mecanismos do poder disciplinar, ele as aproxima de uma perspectiva que de certa forma seria esboçada no texto sobre os homens infames. Todavia, ele ainda permanece na soleira desse arquivo. Isso nos leva a pensar que, embora mais de um autor afirme que o projeto de publicação de uma coletânea de lettres de cachet remonte à História da loucura, ${ }^{25}$ é muito provável que Foucault só o tenha de fato concebido mais tarde, após a conclusão de Vigiar e punir e $A$ vontade de saber, nesse momento de retomada dos projetos editoriais, marcado pelo grande sucesso que foi a publicaçáo de Pierre Rivière. É o que uma rápida comparação entre esse texto programático de 1977 e aquele de 1982 parece sugerir.

$\mathrm{O}$ anúncio do projeto de edição e publicaçáo de uma coletânea de lettres de cachet não prometia uma análise interna desse arquivo. Muito pelo contrário, Foucault ali assegurava ter renunciado a isso em favor de publicá-las na forma como as havia tomado originalmente, sem explicações ou comentários, de modo que não se perdesse sua "intensidade" e o que ele havia sentido ao lê-las pela primeira vez. Por isso, ele abria seu texto afirmando algo inusitado para uma obra que pretendia reunir documentos de arquivo: "Isto não é um livro de história." ${ }^{26}$ De modo ao mesmo tempo surpreendente e corajoso, ele asseverava que a regra que o conduziu em sua escolha foi apenas a de seu "gosto", "prazer", "uma emoção, o riso, a surpresa, um certo assombro ou algum outro sentimento cuja intensidade talvez eu tivesse dificuldade de justificar agora que é passado o primeiro momento da descoberta" ${ }^{27}$ Tratava-se de "uma antologia de existências. De vidas de algumas linhas ou páginas, de

sileira de História da loucura optou por traduzir lettres de cachet por "cartas régias". Histórica, diplomática e tipologicamente, trata-se de uma opção equivocada e que deveria ser revista, pois não dá conta da singularidade do dispositivo a que elas se referem. Entretanto, não é tão desastrosa quanto o modo como se o verteu em português em Vigiar e punir. Primeiramente, o termo foi transposto para "cartas timbradas" (p. 106); na página seguinte, todavia, aparece como "cartas de prego" (p. 107), opção que será em seguida mantida (p. 187; p. 188). Já na questionável edição brasileira dos Ditos e escritos, o termo em francês foi traduzido por "cartas régias com ordem de prisão", indicando-se entre parênteses, em algumas passagens, o original em francês. FOUCAULT, Michel. A vida dos homens infames. Ditos e escritos IV-Estratégias, poder-saber. 2. ed. Rio de Janeiro, Forense, 2006, p. 203-222. Na tradução portuguesa de "A vida dos homens infames", no início dos anos 1990, já se chamava a atenção para o problema da tradução desse termo. Cf. FOUCAULT, Michel. A vida dos homens infames. In:___. O que é um autor? 2. ed. Lisboa: Passagens, 1992, p. 89-128. ${ }^{25}$ DEFERT, Daniel; EWALD, François. [Nota explicativa do texto] La vie des hommes infâmes. Apud FOUCAULT, Michel [1977]. La vie des hommes infâmes, op. cit., p. 237; ERIBON, Didier. Michel Foucault e seus contemporâneos. Rio de Janeiro: Zahar, 1996, p. 158. Logo no início de A vida dos homens infames, Foucault afirmava sem muita convicçáo que a ideia de publicar essa antologia lhe ocorreu quando lia um registro de internamento do início do século XVIII na Biblioteca Nacional. Em seguida, afirmava que "há muito tempo, para um livro, utilizei-me de semelhantes documentos" ["Il y a longtemps, pour un livre, j'ai utilisé de pareils documents"]. FOUCAULT, Michel [1977]. La vie des hommes infâmes, op. cit., p. 238.

26 "Ceci n'est point un livre d'histoire". FOUCAULT, Michel [1977]. La vie des hommes infâmes, op. cit., p. 237.

27 "Une émotion, le rire, la surprise, un certain effroi ou quelque autre sentiment, dont j'aurais du mal peutêtre à justifier l'intensité maintenant qu'est passé le premier moment de la découverte”. Idem. 
“ISSO NẪo É UM LIVRo DE HISTÓRIA": MiCHEL FOUCAUlT E A PUBLICAÇÃO DE DOCUMENTOS DE ARQUIVOS

\section{Marlon Salomon}

infortúnios ou de aventuras sem número, recolhidas numa mão-cheia de palavras. Vidas breves, encontradas ao acaso dos livros e dos documentos" ${ }^{28}$ e "feita um pouco ao sabor do momento". ${ }^{29}$ Todavia, apenas comporiam essa "espécie de herbário" 30 personagens reais, mas que fossem ao mesmo tempo "obscuras" e "desafortunadas", ${ }^{11}$ que "nada tendo sido na história, não tendo desempenhado nenhum papel apreciável nos acontecimentos ou entre as pessoas importantes, náo tendo deixado à sua volta qualquer traço que possa ser referido, não têm e nunca mais terão existência a não ser no abrigo precário das palavras" ${ }^{32}$ Por isso, ele admitia que esse livro "não agradará os historiadores". ${ }^{33} \mathrm{O}$ tom dessa "apresentação" sugeria que essa ingloriosa monumenta da infâmia, se já não estivesse pronta, estava ao menos bastante adiantada. ${ }^{34}$

Les lettres de cachet des Archives de la Bastille seriam publicadas em 1982 em um projeto, todavia, um pouco diferente daquele que Foucault havia concebido para ser essa "grande coletânea da infâmia". ${ }^{35}$ Há dois grandes conjuntos de lettres de cachet reunidos tematicamente em Le désordre des familles: o primeiro intitula-se "A discórdia dos lares"; o segundo, "Pais e filhos"; finalmente, há um ensaio intitulado "Dirigindo-se ao rei". Como se vê, a ideia original de publicá-las "em sua secura" 36 cedia espaço a uma apresentação geral dessa papelada e longos comentários de abertura de cada conjunto documental. Do mesmo modo, a recolha aleatória dava lugar a duas séries temáticas de documentos organizados de maneira cronológica. ${ }^{37}$ Finalmente, o próprio ponto de partida do projeto inicial via-se deslocado. Em sua "apresentação", Foucault e Farge declaravam que o que mais os havia impressionado na leitura desses documentos foram as solicitaçôes, diretamente enviadas ao rei ou ao tenente de

\footnotetext{
28 "Une anthologie d'existences. De viés de quelques lignes ou de quelques pages, des malheurs et des aventures sans nombre, ramassés en une poignée de mots. Vies brèves, rencontrées au hasard des livres et des documents". Idem. Observe-se que Foucault não afirmava reduzir sua recolha às lettres de cachet, embora deixasse claro sua preponderância entre os documentos que alimentariam sua coleção. A coletânea prometia reunir "documentos que datam, todos, mais ou menos da mesma centena de anos, 1660-1760, provenientes da mesma fonte: arquivos de internamento, da polícia, das petiçóes ao Rei e das lettres de cachet. Ibidem, p. 243. 29 "Faite un peu selon l'occasion". Ibidem, p. 238.

30 "Sorte de herbier". Ibidem, p. 237.

${ }^{31}$ Ibidem, p. 239.

32 “N'ayant rien été dans l'histoire, n'ayant joué dans les événements ou parmi les gens importants aucun rôle appréciable, n'ayant laissé autor d'eux aucune trace qui puisse être référée, ils n'ont et n'auront plus jamais d'existence qu'à l'abri précaire de ces mots". Ibidem, p. 242.

33 "Ce livre ne fera donc pas l'affaire des historiens". Ibidem, p. 239.

${ }^{34}$ Ele o afirma claramente: "Recolha que foi composta sem pressa e sem uma finalidade claramente definida" ("Recueil qui s'est composé sans hâte et sans but clairement defini”). Ibidem, p. 238.

35 "Grand recueil de l'infamie". Ibidem, p. 243.

36 "Dans leur sécheresse". Ibidem, p. 238.

${ }^{37}$ Essa coletânea se reduzirá a documentos colhidos nos arquivos das lettres de cachet entre os anos de 1728 e 1758. Localizei na coletânea de 1982 ao menos uma lettre que Foucault cita em 1977: a de um certo Duchesne. Cf. Ibidem, p. 244; FOUCAULT, Michel; FARGE, Arlette. Le désordre des familles. Lettres de cachet des Archives de la Bastille, op. cit., p. 76. Isso tudo parece sugerir, ao contrário do que o filósofo francês afirma, que em 1977 o trabalho era ainda incipiente.
} 
“ISSO NẪ É UM LIVRo DE HISTÓRIA": MiChEl FOUCAUlT E A PUBLICAÇÁO DE DOCUMENTOS DE ARQUIVOS

\section{Marlon Salomon}

polícia, "para se obter do soberano uma 'ordem' restringindo a liberdade de um indivíduo", 38 em geral, de encarceramento. Também os havia surpreendido o fato de que, em muitos casos, essas petiçóes dissessem respeito a pequenos conflitos familiares (entre pais e filhos, a respeito da má conduta de um dos cônjuges) e privados (desentendimentos domésticos), em sua grande maioria oriundas de meios muito modestos; a toda aquela infrapenalidade da qual Foucault falava em 1975. Malgrado o aspecto lacunar desses documentos, essas petiçóes eram seguidamente acompanhadas de uma série de outros: atestados, inquéritos policiais, decisão do rei e pedidos de libertação (das vítimas ou mesmo daqueles que haviam originalmente solicitado sua prisão). Por essa razão, eles acreditavam que o interesse dessa documentação (e sua publicação) estava no fato de ela fornecer perspectivas sugestivas "sobre toda uma vida cotidiana nas classes populares de Paris" 39 durante certo período do Antigo Regime. A leitura desses documentos sugeria algo bastante distinto da tendência comum Foucault sempre insistiu nisso — de se enxergar nas lettres o arbítrio real por meio do qual buscava-se encerrar os inimigos do poder nas sombras da Bastilha, cuja queda a história imortalizou como símbolo do fim do jugo absolutista. "A leitura desses dossiês nos colocou na pista antes das paixóes da arraia-miúda, no centro das quais se acham as relações de família — maridos e mulheres, pais e filhos — , do que das cóleras do soberano." ${ }^{40} \mathrm{O}$ projeto original tornou-se, portanto, um estudo sistemático de dois grandes conjuntos tematicamente organizados de lettres de cachet. Não há, sem dúvida, interpretaçóes desses documentos. Eles são antes descritos, a prática que torna possível esse arquivo é situada historicamente e, no final do livro, apresentam-se "algumas perspectivas" ${ }^{11}$ que se depreendem da leitura dessa massa documental. ${ }^{42}$ Saem de cena os infames e entra em seu lugar esse saber das classes populares oriundo de uma prática que, no limite, ao desviar-se do recurso à justiça comum, procura evitar não apenas a sua lentidão tradicional, mas sobretudo a infâmia e a desonra

\footnotetext{
38 "Pour obtenir du souverain un 'ordre' restreignant la liberte de l'individu". FOUCAULT, Michel; FARGE, Arlette. Le désordre des familles. Lettres de cachet des Archives de la Bastille, op. cit., p. 9.

39 "Sur toute une vie quotidiene dans les classes populares de Paris". Ibidem, p. 10.

40 "La lecture de ces dossiers nous a mis sur la trace moins des colères du souverain que des passions du menu peuple, au centre desquelles on trouve les relations de famille — maris et femmes, parentes et enfants". Idem. ${ }^{41}$ Idem.

${ }^{42}$ Em 1977, ele escrevia que, inicialmente, "o sonho teria sido o de restituir sua intensidade em uma análise. À falta do talento necessário, durante muito tempo, fiquei remoendo essa análise" ["Le rêve aurait été de restituer leur intensité dans une analyse. Faute du talent nécessaire, j’ai donc longtemps remâché la seule analyse"]. Ele procurou, então, compreender a razão de ser desses documentos, a que instituiçóes e práticas políticas pertenciam etc. Todavia, isso parecia afastá-lo dessa "intensidade" inicial provocada por sua leitura. "Mas as intensidades primeiras que me haviam motivado permaneciam no exterior [dessa análise]. E visto que havia o risco de elas não passarem à ordem das razóes, uma vez que meu discurso era incapaz de comportá-las como deveria ser, não seria melhor deixá-las na própria forma por meio da qual eu as havia experimentado"? [Mais les intensités premières qui m’avaient motivé restaient au dehors. Et puiqu'il y avait risque qu'elles ne passent point dans l'ordre des raisons, puisque mon discours était incapable de les porter comme il aurait fallu, le mieux n'était pas de les laisser dans la forme même que me les avait fait éprouver?"]. FOUCAULT, Michel [1977]. La vie des hommes infâmes, op. cit., p. 238.
} 
"ISSO NÂO É UM LIVRO DE HISTÓRIA": MiChEl FOUCAUlT

que a exposição pública de um membro da família em um processo judicial certamente implicariam.

Hoje, sabemos que o objetivo original de Foucault de publicá-los sem explicaçôes ou comentários mudou a partir de seu encontro com Arlette Farge. Ao contrário das sãs recomendaçóes metodológicas, sabe-se que o autor de $A$ arqueologia do saber era, para não dizer avesso, econômico quando se tratava de citar e recorrer a "referências bibliográficas" sobre os assuntos de seus estudos. Entretanto, entre os raros trabalhos historiográficos que ele havia citado em seu livro sobre as prisóes, figurava a tese de doutorado de Farge ${ }^{43}$ sobre a criminalidade no século XVIII. ${ }^{44}$ Autodidata, pois sem formação em história, trânsfuga da escola de direito, Farge iniciou seu trabalho sobre os arquivos judiciários sob a orientação e exortação de Robert Mandrou. ${ }^{45}$ Em 1979, ela publicou Vivre dans la rue à Paris au XVIII siècle, livro em que reunia extratos de textos oriundos dos arquivos judiciários entremeados por explicações e comentários, no qual procurava, na esteira de Faire de l'histoire, inventar novos domínios de investigação pensando a "rua como objeto histórico", e no qual também reconhecia sua dívida com a análise de Foucault, que "incitava a interrogar as fontes com novas perspectivas" ${ }^{46}$ Esse livro foi lançado pela "Coleção Arquivos" da editora Gallimard, voltada para a compilação de documentos históricos comentados e na qual já havia sido publicado o dossiê sobre Rivière. Foucault provavelmente leu esse livro quando de sua publicação e convidou Farge para trabalhar com ele na edição das lettres de cachet. Le désordre des familles seria publicado em seguida na mesma "Coleção Arquivos", 47 com comentários e explicaçóes semelhantes àqueles que encontramos em Vivre dans la rue. Sem dúvida, Foucault havia "descoberto" as lettres de cachet, que poucos haviam lido e trabalhado até então. Com Farge, Foucault poderia contar com o apoio de uma especialista nos arquivos judiciários do século XVIII. Esse convite também sugere que Foucault já se afastava lentamente do projeto original anunciado em 1977 e que muito provavelmente a leitura de Vivre dans la rue lhe indicava alguma direção. Já não se podia mais dizer "que isso não é um livro de história”.

O que importa, todavia, é que o trabalho com esses documentos de arquivo o colocava diante de uma experiência bastante surpreendente em relação à leitura de textos filosóficos ou literários. Esses documentos permitiam pensar nesses tipos obscuros, que pertencem

\footnotetext{
${ }^{43}$ No tópico "A punição generalizada". Cf. FOUCAULT, Michel. Vigiar e punir. História da violência nas prisóes, op. cit., p. 117.

${ }^{44}$ Le Vol d'aliments à Paris au XVIII siècle seria publicado pela editora Plon a partir da indicaçáo do mesmo coordenador de coleção que havia, quinze anos antes, sugerido à Plon a publicação da tese de doutorado de Michel Foucault: Philippe Ariès. Cf. FOUCAULT, Michel [1984]. Le style de l'histoire. In: Dits et écrits, op. cit., p. 1468 [Texto no 348]; VIDAL, Laurent. Arlette Farge, le parcours d'une historienne. Entretien avec Laurent Vidal. Genèses, 2002, n. 48, p. 116.

45 Que dizia nessa época dos arquivos judiciários: "Esse imenso fundo que nunca havia sido descoberto." VIDAL, Laurent. Arlette Farge, le parcours d'une historienne. Entretien avec Laurent Vidal, op. cit., p. 115. 46 "Incitait à interroger les sources avec de nouvelles perspectives." FARGE, Arlette. Vivre dans la rue à Paris au XVIII siècle. Paris: Gallimard/Julliard, 1979, p. 10.

${ }^{47}$ Dirigida por Pierre Nora e Jacques Revel.
} 
“ISSO NẪ É UM LIVRo DE HISTÓRIA": MiChEl FOUCAUlT

“àqueles bilhóes de existências que estão destinadas a passar sem deixar traços". ${ }^{8}$ A existência desses documentos que permite conhecê-las, mesmo que muitas vezes de forma lacunar, não resulta do acaso e nem tampouco é um legado do passado, pois para que algo delas se transformasse em registro, foi necessário "que um feixe de luz, por um instante ao menos, viesse iluminá-las". ${ }^{49} \mathrm{O}$ que as transforma em arquivo e as arranca da noite do esquecimento "em que elas poderiam e talvez devessem sempre ter ficado é o encontro com o poder: sem esse contato, sem dúvida, nenhuma palavra teria chegado até nós para lembrar seu fugidio trajeto" ${ }^{50}$ Eis uma condição primeira ou pré-epistemológica do objeto histórico. O esclarecimento da história depende dessa luz primeira. É por essa razão que $A$ vida dos homens infames não pretende interpretar esse acervo, mas fazer uma genealogia desse mecanismo de registro que o historiador toma em seguida como um documento ou dado de arquivo. O que está em jogo na arquivologia foucaultiana não é uma fenomenologia dos rastros, mas uma análise do que os torna possível, isto é, uma análise dos tipos de estratégias de poder que tornam possível o arquivo como saber. ${ }^{51}$ Daí a aproximação da história com a arqueologia: é preciso tratar os documentos como monumentos. Rivière, Barbin e os peticionários populares de Paris saem das sombras da não-história e "aparecem" diante do poder. Não é uma hermenêutica ou uma analítica, mas uma exposição desses documentos de arquivo o que importa nesse projeto editorial.

Creio que poderia doravante, na segunda parte deste texto, insistir sobre duas questóes que parecem estar em jogo nessa encenação do arquivo que atravessa esses projetos editoriais do filósofo francês e que dizem respeito aos saberes literário e histórico.

\section{O cerco arquivístico da literatura}

Já em 1973, o memorial de Rivière permitia colocar em questão as noções de "obra", "texto" e de "análise textual". "Visto que a lei de sua existência e de sua coerência não é nem a de uma obra nem a de um texto, seu estudo deve permitir manter afastados os velhos métodos acadêmicos da análise textual." 52 Do mesmo modo, esses textos punham em xeque a noção de "autoria”. Se, sem dúvida, há alguém que os escreveu (ou os fez escrever), esse alguém não poderia ser chamado de “autor”. Há apenas uma existência “por detrás de

\footnotetext{
48 "À ces milliards d'existences qui sont destinées à passer sans traces". FOUCAULT, Michel [1977]. La vie des hommes infâmes, op. cit., p. 240.

49 "Qu'un faisceau de lumière, un instant au moins, vienne les éclairer". Idem.

50 "Où elles auraient pu, et peut-être toujours dû, rester, c'est la reencontre avec le pouvoir: sans ce heurt, aucun mot sans doute ne serait plus là pour rappeler leur fugitif trajet”. Idem.

${ }^{51}$ Vê-se como nessa época, ao contrário da década anterior, ele define o poder como pré-condição do saber dos arquivos.

${ }^{52}$ FOUCAULT, Michel [1973]. Eu, Pierre Rivière, que degolei minha mãe, minha irmã e meu irmão..., op. cit., p. 14.
} 


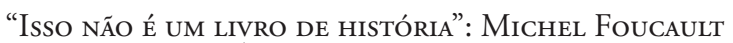

nomes que não dizem mais nada". ${ }^{53}$ Com esses textos, era, portanto, uma ordem do discurso literário que era visada.

Isso não significa que se tratava de relatos totalmente sem referência. Antes de redigi-lo a pedido do magistrado, Rivière o havia composto "em sua cabeça" ${ }^{54}$ Foucault identifica sua forma "a toda uma série de narrativas que formavam então como que uma memória popular dos crimes". 55 Trata-se de narrativas sobre crimes que circulavam em panfletos e folhetos, que ampliavam e davam uma escala maior a fatos reportados em jornais, que abriam "ao quotidiano o acesso da narraçáa" 56 que, fazendo entrar na narrativa uma série de elementos, objetos, acontecimentos, relatos orais a respeito, tornavam possível sua "passagem para escrita" ${ }^{57}$ Já em My Secret Life, seu autor sem nome fez um "relato meticuloso" de uma vida essencialmente consagrada ao prazer sexual, contando, sem retórica ou fastio, suas menores experiências, segundo sua intensidade e suas sensaçôes. Nessa "tarefa de escrever o cotidiano de seu prazer", Foucault identificava ao menos três formas concomitantes em sua composiçẫo: a mais antiga é aquela que no Ocidente, desde a Idade Média, ligada à penitência e ao exame de consciência, obrigou a buscar em si "os próprios traços imperceptíveis da concupiscência". ${ }^{58}$ Em seguida, aquela que, de Rétif e Sade, transformou a literatura erótica em uma busca obstinada da verdade do prazer, caracterizando a nova "libertinagem" do século XVIII como "uma erótica da verdade" ${ }^{59}$ Finalmente, a mais recente e talvez a mais importante seja aquela que orientava a medicina e a psiquiatria da época de sua redação na direção de "um interesse quase entomológico pelas práticas sexuais, seus variantes e todo seu disparate". Foucault se referia aqui à Psychopathia sexualis de R. von Krafft-Ebing. Nas memórias de Barbin, Foucault reconhecia um tipo de escrita que era comum nos pensionatos femininos do século XIX, "com esse estilo elegante, organizado, alusivo, um pouco enfático e antiquado que era para os pensionatos de então não somente uma maneira de escrever, mas uma maneira de viver". ${ }^{60}$

Vê-se como a composição desses textos partia de referências e concepçóes de escrita exteriores ao campo literário do século XIX. A transformação do cotidiano em escrita, a escriturização do dia a dia, a mise en discours da vida ordinária faziam-se por aí. Mas isso

\footnotetext{
53 "Derrière ces noms qui ne disent plus rien". FOUCAULT, Michel [1977]. La vie des hommes infâmes, op. cit., p. 239.

${ }^{54}$ FOUCAULT, Michel [1973]. Eu, Pierre Rivière, que degolei minha mãe, minha irmã e meu irmão..., op. cit., p. 288.

${ }^{55}$ Ibidem, p. 290.

${ }^{56}$ Idem.

${ }^{57}$ Ibidem, p. 291.

58 "Tâche d'écrire le quotidien de son plaisir"; "les traces même imperceptibles de la concupiscence". FOUCAULT, Michel [1976]. L'Occident et la vérité du sexe, op. cit., p. 102.

59 "Une érotique de la vérité". Idem.

60 "Avec ce style élégant, apprêté, allusif, un peu emphatique et désuet qui était pour les pensionnats d’alors non seulement une façon d'écrire, mais une manière de vivre." FOUCAULT, Michel [1980]. Le vrai sexe, op. cit., p. 938. v. II [Texto no 287 ].
} 
não os transformava em textos com estatuto literário ou seus redatores em autores. Em $A$ ordem do discurso, o filósofo francês lembrava que um autor não deveria ser entendido como o indivíduo que pronunciou ou redigiu um texto, mas "como princípio de agrupamento do discurso, como unidade e origem de suas significaçôes, como foco de sua coerência" ${ }^{61}$ Ele lembrava, em seguida, que esse princípio de identificação não existia em toda parte e nem era uma constante. Há discursos que circulam sem essa identificaçáo. Entretanto, desde o século XVII, na ordem do discurso literário, "a função do autor não cessou de se reforçar", ${ }^{6}$ pois "o autor é aquele que dá à inquietante linguagem da ficção suas unidades, seus nós de coerência, sua inserção no real". ${ }^{63}$

Mas é em $A$ vida dos homens infames que a problematização do estatuto desses escritos fica mais explícita. Já no início, Foucault denomina de "novelas" essas "vidas de algumas linhas ou algumas páginas" que recolheria em sua seleta. Com essa denominação, não se tratava de aproximá-las dos gêneros consagrados da poética. Era "a rapidez da narrativa e a realidade dos acontecimentos reportados" o que lhe valia essa designação. De várias maneiras, ele procurava demarcar a diferença entre essas "existências-clarão", esses "poemas-vida", e a literatura. Num primeiro registro, pela intensidade desses textos e pelo efeito de sua leitura. "Confesso que tais 'novelas', surgindo de súbito por entre dois séculos e meio de silêncio, tocaram-me a sensibilidade de forma mais profunda do que aquilo a que vulgarmente chamamos de literatura." ${ }^{64}$ Num segundo, em função de sua relação com a realidade. Assim, ele excluiu de sua coletânea "tudo que pudesse ser [obra da] imaginação ou literatura"; ${ }^{5}$ do mesmo modo, aqueles que estivessem a certa distância da realidade, por sua relação com ela ser mediada pela memória, lembrança etc. "Fiz questão de que esses textos mantivessem sempre uma relação, ou antes, o maior número de relaçóes possíveis com a realidade: não somente que se referissem a ela, mas que nela operassem." ${ }^{66}$ Não era o valor representativo desses textos, sua maior exatidão ou fidelidade em relação à realidade o que aí importava, mas o fato de terem "desempenhado um papel nesse real do qual falam" ${ }^{67}$

Por isso, ele os chamava de "peça[s] da dramaturgia do real", ${ }^{68}$ pois constituíam-se como instrumentos de uma vingança, arma de um ressentimento, "episódio em uma batalha",

\footnotetext{
${ }^{61}$ FOUCAULT, Michel. A ordem do discurso. 2. ed. Tradução de Laura Sampaio. São Paulo: Loyola, 1996, p. 26.

${ }^{62}$ Ibidem, p. 27.

${ }^{63}$ Ibidem, p. 28.

64 “J'avoue que ces 'nouvelles', surgissant soudain à travers deux siècles et demi de silence, ont secoué en moi plus de fibres que ce qu'on appelle d'ordinaire la littérature." FOUCAULT, Michel [1977]. La vie des hommes infâmes, op. cit., p. 238.

65 "Tout ce qui pouvait être imagination ou littérature". Ibidem, p. 239.

66 "J'ai tenu à ce que ces textes soient toujours dans un rapport ou plutôt dans le plus grand nombre de rapports possibles à la réalité: non seulement qu'ils s’y réfèrent, mais qu'ils y opèrent." Idem.

67 "Ont joué un rôle dans ce réel dont ils parlent". Ibidem, p. 240.

68 "Pièce dans la dramaturgie du réel". Idem.
} 
“ISSO NẤ É UM LIVRO DE HISTÓRIA": MiChel FouCAUlt

uma súplica. Eram armadilhas, gestos, "intrigas cujos instrumentos foram as palavras" ${ }^{69}$ Por essa razão, Foucault via nesse "teatro do cotidiano", constituído em torno das lettres de cachet e desses documentos de arquivo dos séculos XVII e XVIII, "um começo" ${ }^{70}$ Em torno da confissão, o cristianismo havia organizado a "tomada do poder sobre o cotidiano": obrigação de fazer passar pela linguagem o minúsculo da vida e suas faltas, pensamentos, desejos, intençôes. ${ }^{71}$ No final do século XVII, "esse mecanismo foi enquadrado e ultrapassado por um outro cujo funcionamento era muito diferente" ${ }^{72}$ Ele deixava de ser religioso e se tornava administrativo; passava a ser de registro e não mais de perdão. Mas Foucault vê, em parte, uma continuidade em sua finalidade: a mise en discours, a "discursificação" do cotidiano, a "revista do universo ínfimo das irregularidades e das desordens sem importância" para a qual concorrerá toda uma série de procedimentos (denúncia, inquérito, relatório, interrogatório) com o objetivo de registrá-lo por escrito. Uma nova relação entre poder, discurso e cotidiano se constituía aí; o dia a dia passava a ser gerido e formulado de uma nova maneira. Com ela, nascia uma nova encenação para a vida ordinária.

O mais interessante é que Foucault afirma que as lettres de cachet foram os instrumentos arcaicos dessa nova encenação. Com esse dispositivo, nasce uma infinidade de discursos "que atravessam em todos os sentidos o cotidiano" e que se encarregam do "mal minúsculo das vidas sem importância". Com ele, houve "imenso e onipresente apelo à discursificação de todas" as agitaçóes e miudezas da vida ordinária. ${ }^{73}$ "Nascimento, pois, de uma imensa possibilidade de discurso." ${ }^{74}$ Isso nos permite claramente relacionar esse dispositivo com os três textos do século XIX editados pelo filósofo francês nos anos 1970. A “colocação do sexo em discurso", "a incitação aos discursos", a escrita do "cotidiano" de seu próprio prazer, a "abertura ao cotidiano à narração" etc., encontrariam nas lettres uma espécie de "começo", quer dizer, não uma origem, mas o nascimento, a abertura de um campo de possibilidades discursivas. E a literatura não seria indiferente a esse acontecimento. Desse modo, creio que A vida dos homens infames seja indissociável desse interesse e desse gesto editorial, pois a análise desse dispositivo se constitui como uma espécie de genealogia desses discursos do século XIX em cuja história as lettres marcariam data importante.

Mas essa genealogia não se encerra aí. Essa papelada marcava o momento em que a massa anônima do povo passava a falar de si mesma, mesmo que essa fala circulasse no interior de um dispositivo de poder. De um poder que não incitava apenas a agir, mas também a "falar". ${ }^{75}$ E isso marcava um acontecimento no qual a literatura estaria comprometida. Até o

\footnotetext{
69 "Des intrigues dont les mots ont été les instruments". Idem.

${ }^{70}$ Ibidem, p. 244.

${ }^{71}$ Ibidem, p. 245.

72 "Ce mécanisme s'est trouvé encadré et débordé par un autre dont le fonctionnement était três différent". Idem.

${ }^{73}$ Ibidem, p. 248.

74 "Naissance, donc, d'une immense possibilité de discours." Idem.

75 Ibidem, p. 251.
} 
século XVII, o dia a dia só poderia ser alçado ao discurso se fosse transfigurado pelo "fabuloso": gestos de heroísmos, aventuras e façanhas que o arrancassem para fora de si. A partir de entáo, "o Ocidente viu nascer toda uma 'fábula' da vida obscura de onde o fabuloso se achou proscrito". ${ }^{76}$ Nasce o que Foucault denomina de "arte da linguagem" 77 que náo quer cantar o improvável, mas tratar do que não é evidente, do que não merece glória, "dos graus últimos do real". O infame aparece aí e com ele "forma-se um novo imperativo que vai constituir o que poder-se-ia chamar a ética imanente ao discurso literário do Ocidente". Lentamente, ela perde suas "funçôes cerimoniais" e retóricas e passa a tratar "daquilo que é mais difícil notar", o mais oculto, interdito e escandaloso. Uma nova injunção, uma nova "moral", uma "ética discursiva" fará a literatura se voltar para a "parte a mais noturna e a mais cotidiana da existência", a do "dever de dizer o mais comum dos segredos" ${ }^{78} \mathrm{E}$ se a literatura náo se reduz a isso, Foucault dirá que é aí, nessa política, "que ela tem o seu lugar e as suas condiçôes de existência". ${ }^{79}$ Mais do que qualquer outra forma de linguagem, ela "permanece como o discurso da infâmia", do segredo, do oculto — o que explica a fascinação mútua entre ela e a psicanálise.

Vê-se a razão pela qual se pode situá-la historicamente em relação às lettres de cachet $\mathrm{e}$ flanqueá-la com os textos do século XIX que o filósofo francês se interessou em publicar. Assim como a literatura, eles fazem "parte daquele grande sistema de coação pelo qual o Ocidente obrigou o cotidiano a pôr-se em discurso". ${ }^{80}$ Todavia, eles não pertencem ao cânone literário e sequer foram considerados no interior das artes da linguagem. Trata-se de "textos" reduzidos ao silêncio. São "textos" redigidos por indivíduos que não preenchem a funçấo-autor, que estão no exterior da literatura, que vagam às margens do saber literário, que pertencem à "teratologia do saber" ${ }^{11}$ literário, que não funcionam como literatura, mas que permitem expor as regras de formação do discurso literário.

É a dicotomia - que a análise genética jamais pôs em questão - entre arquivo e biblioteca que desaparece na análise de Foucault. Em sua análise, a biblioteca, que duplica ou dispóe biblioteconomicamente a ordem do discurso literário, é cercada, circundada, sitiada pelo arquivo, que reúne a (des)ordem do discurso em seu nível meramente textual (as lettres e os textos infames). E isso nos permite compreender as regras de inscrição institucional e epistêmica de certos textos no interior dela (o que entra ou não em uma biblioteca).

\footnotetext{
76 "L'Occident a vu naître toute une 'fable' de la vie obscure d'où le fabuleux s'est trouvé proscrit". Ibidem, p. 252.

${ }^{77}$ Idem.

78 "Un nouvel impératif se forme qui va constituer ce qu'on pourrait appeler l'éthique imanente au discours littéraire de l'Occident"; "la part la plus nocturne et la plus quotidienne de l'existence"; "devoir de dire le plus comuns des secrets". Idem.

79 "Mais elle y a son lieu et ses conditions d'existence". Idem.

80 "Partie de ce grand système de contrainte par lequel l'Occident a obligé le quotidien à se mettre en discours". Idem.

${ }^{81}$ FOUCAULT, Michel. A ordem do discurso, op. cit., p. 33.
} 
“ISSO NẪ É UM LIVRo DE HISTÓRIA": MiChEl FOUCAUlT E A PUBLICAÇÁO DE DOCUMENTOS DE ARQUIVOS

\section{Marlon Salomon}

Uma vez vencido esse assédio, é possível pensar esses textos fora do espaço do livro e de sua evidência biblioteconômica. Os náo-textos, os não-autores e a anormalidade escriturária que está "fora" do espaço literário cercam-na até o ponto em que essa clivagem desaparece e o limite entre o textual e o infratextual se dissolve. É no espaço dessa dissolução que Foucault situa análise.

Isso nos levaria a pensar que Foucault não necessariamente tenha se desinteressado pela literatura nos anos 1970. Todavia, sua perspectiva não é mais biblioteconômica. O advento do arquivo reconfigurou seu olhar. Sem dúvida, estamos longe da importância que ela ocupou em seu trabalho durante a década anterior, quando fora profundamente marcado por Blanchot e pela ideia da literatura como obra de linguagem. A literatura então era linguagem e essa linguagem era intransitiva. Nos anos 1970, não seria mais em um Flaubert que se encontraria a beleza literária, mas em textos como os de Rivière: "sua beleza apenas já seria suficiente para preservá-lo", ${ }^{82}$ isto é, para inscrevê-lo na ordem dos livros. E se "Foucault jamais realizou propriamente uma arqueologia da literatura", como demonstra Roberto Machado, ${ }^{83}$ poderíamos pensar se esses textos dos anos 1970 não nos colocam, de um lado, na trilha de uma genealogia do saber literário ou ao menos de seu esboço e, de outro, se não prologam a crítica exposta em $A$ arqueologia do saber à naturalização do emprego de noçóes tais como obra, autor, livro etc. ${ }^{84}$ No prolongamento que se pode identificar nesse projeto editorial, desta feita, é a crítica à própria categoria de literatura como "princípio de classificação" dos textos, com suas "regras normativas, tipos institucionalizados" e o que define a literariedade de um texto o que está em jogo. ${ }^{85}$ Para que o objeto da literatura fosse possível era preciso, antes, que a vida ordinária, que o cotidiano, que o inevidente das vidas obscuras, que o ínfimo da vida, que o jour le jour fosse transformado em escrita. O que torna possível a matéria poética é essa promoção prévia que possui, como queria Foucault, uma beleza superior àquela que se encontra na literatura. E se Foucault refere-se a esses textos como "graus últimos do real", possivelmente, numa alusão a O grau zero da escrita, é porque se trata não de uma história da escrita, como queria Barthes, mas da "escriturização", quer dizer, dos dispositivos que transformam algo em matéria escrita. O grau zero da escriturização que torna possível a literatura. $\mathrm{O}$ espaço da escriturização dissolve as fronteiras entre o arquivo e a biblioteca. É essa cena anterior à literária que ele busca expor com a publicação desses documentos.

\footnotetext{
${ }^{82}$ FOUCAULT, Michel [1973]. Eu, Pierre Rivière, que degolei minha mãe, minha irmã e meu irmão..., op. cit., p. 285.

${ }^{83}$ MACHADO, Roberto. Foucault, a flosofia e a literatura. Rio de Janeiro: Zahar, 2000, p. 121.

${ }^{84}$ Já n’A Arqueologia do Saber ele se questionava sobre a possibilidade não de dispensá-las, mas de pensar noçôes como "obra" ou "livro" ou unidades como "ciência" e "literatura" a partir de outras perspectivas. "Tratase, de fato, de arrancá-las de sua quase-evidência, de liberar os problemas que colocam; reconhecer que não são o lugar tranquilo a partir do qual outras questóes podem ser levantadas (...) Trata-se de reconhecer que elas talvez não sejam, afinal de contas, o que se acreditava que fossem à primeira vista.” FOUCAULT, Michel [1969]. A arqueologia do saber. 2. ed. Rio de Janeiro: Forense, 1986, p. 29.

${ }^{85}$ Ibidem, p. 26.
} 
"ISSO NÂO É UM LIVRO DE HISTÓRIA": MiChEl FOUCAUlT E A PUBLICAÇÁO DE DOCUMENTOS DE ARQUIVOS

\section{Marlon Salomon}

\section{Diante da História}

Gostaria de considerar esse gesto filosófico diante do pensamento histórico da época e pensar se o que está em jogo aí, por outro lado, não é a própria relação entre, de um lado, o estatuto das falas que se lê nos rastros deixados por aqueles que não entraram para a história e, de outro, com a palavra do filósofo que, conscientemente, não quer ocupar o seu lugar, falar delas, falar em seu lugar, dar a elas um sentido histórico.

O primeiro aspecto diz respeito a algo que me parece importante em relaçáo à historiografia da época e à posiçáo de Foucault diante dela. Nas décadas de 1960 e 1970, o pensamento histórico foi profundamente marcado por ao menos duas grandes tendências na historiografia francesa: a história demográfica e quantitativa, de um lado, e a história das mentalidades, de outro. Nos Annales, essa primeira tendência era bastante representativa por meio da história serial. Tratava-se de uma história fundada nos princípios de "contagem e de quantificação na pesquisa histórica". ${ }^{86}$ Reação à história econômica, a história das mentalidades tomava como pressuposto a dissolução da singularidade no geral: "Seu objeto é o coletivo." ${ }^{87}$ Uma mentalidade era formada exatamente pelo conjunto de crenças que um indivíduo concreto partilhava com os homens de seu tempo. Ela se voltava, portanto, ao "nível mais estável, mais imóvel das sociedades" ${ }^{88} \mathrm{O}$ necessário das determinaçôes estatísticas e a dissoluçáo do singular no geral: eis a historiografia dessa época, de certa maneira, tratando de se conciliar com as injunçóes epistemológicas da Poética. ${ }^{89}$ De um lado, o acontecimento e a singularidade eram rechaçados em nome da repetiçấo regular de dados ordenados em unidades homogêneas $;{ }^{90}$ de outro, eram desconsiderados em nome da imobilidade do tempo e da dissolução do singular no coletivo.

Vê-se claramente que a "ordem" em que Foucault gostaria de publicar os textos de anônimos ou de apresentar suas lettres de cachet escapa fortemente a essas tendências. O objetivo de Foucault com a publicação, quase que de forma bruta, desses documentos, era, contra as recomendaçôes científicas, o de deixá-los "falar por si mesmos", de "dar voz" a esses personagens obscuros, a esses anônimos que não "fizeram" a história. Sublinhe-se: não se trata de personagens marginais da história, mas de personagens que não têm história, que não têm lugar na história. Para a história das mentalidades, por exemplo, uma fala qualquer só poderia fazer sentido na medida em que expressasse um sistema de crenças. ${ }^{91}$ Daí que não se

\footnotetext{
${ }^{86}$ FURET, François [1974]. O quantitativo em história. In: LE GOFF, Jacques; NORA, Pierre. História: novos problemas. 4. ed. Tradução de Theo Santiago. Rio de Janeiro: Francisco Alves, 1995, p. 49.

${ }^{87}$ LE GOFF, Jacques [1974]. As mentalidades: uma história ambígua. In: LE GOFF, Jacques; NORA, Pierre. História: novas abordagens. 4. ed. Tradução de Terezinha Marinho. Rio de Janeiro: Francisco Alves, 1995, p. 69. ${ }^{88}$ Idem.

${ }^{89}$ Sobre isso, ver RANCIÈRE, Jacques. Les noms de l'histoire: Essai de poétique du savoir. Paris: Seuil, 1992. ${ }^{90}$ FURET, François [1974]. O quantitativo em história. In: LE GOFF, Jacques; NORA, Pierre. História: novos problemas, op. cit., p. 51.

${ }^{91}$ LE GOFF, Jacques [1974]. As mentalidades: uma história ambígua. In: LE GOFF, Jacques; NORA, Pierre. História: novas abordagens, op. cit., p. 71.
} 
“ISSO NẪo É UM LIVRo DE HISTÓRIA": MiCHEL FOUCAUlT

tratava de dar voz a elas, mas, ao contrário, colocá-las em seu devido lugar, fazer exatamente falar nelas isso que não fala e que elas ignoravam, o fato de testemunharem a mentalidade coletiva de uma época, partilharem com homens e mulheres de estratos, classes e formações diferentes de uma época o mesmo conjunto de crenças.

No projeto arquivístico-editorial de Foucault não se trata de assinalar a cultura campesina de Rivière ou a mentalidade religiosa de Barbin. Não devemos esquecer que esses documentos pertenciam aos arquivos judiciários e de polícia, que reúnem a matéria considerada desprezível da história da sociedade. São os materiais pertencentes ao mundo dos anônimos e desclassificados sociais; não daqueles que estão à parte do mundo social, mas daqueles que não têm parte nele; dessas vidas estranhamente paralelas à história. São os documentos que reúnem os traços deixados pelos homens e mulheres exteriores ao mundo dito normal. Donde o problema de como o intelectual, historiador ou náo, se relaciona e o que ele faz com esses traços. Vemos que Foucault evita o procedimento tipicamente historiográfico: não se trata de buscar reconstituir ou fazer falar por meio deles formas de sociabilidade (operária, feminina, por exemplo) ou traduzir a cultura que elas expressam (rural etc.); de silenciar sua tagarelice para "fazer falar" o que nelas é mudo; mas de pensá-las em sua singularidade e como acontecimento: o fato de que os marginais, anônimos e aqueles que não têm lugar no mundo social "falam"; eles falam fora de lugar, falam fora da verdade; como insisti anteriormente, Foucault considerava um acontecimento o momento em que a massa anônima do povo passava a falar de si mesma. Era isso que ele destacava em seu texto sobre os homens infames: não se tratava de interpretar esses textos, mas descrever o acontecimento que marca o momento em que o homem comum passa a falar de si mesmo e entra, portanto, na história, isto é, no arquivo. Por isso, ele não via nos documentos uma obscuridade que fosse preciso iluminar, mas um clarão cuja intensidade era preciso restabelecer.

Nesse sentido, o trabalho de Michel Foucault marcou um novo tipo de interesse pela história das palavras e das falas. A questão filosófica decisiva que podemos situar aí não é o interesse em interpretá-los, mas dar voz a discursos, falas, que haviam sido rechaçados ou anulados pela palavra da ciência: transformados em dados estatísticos homogêneos ou dissolvidos na generalidade do mental. Mas esse interesse pela história das palavras não era indiferente a um novo estatuto que então se atribuía aos discursos assim ditos não científicos ou não literários. Dar voz e fazer circular falas e discursos desclassificados era um programa ao mesmo tempo epistêmico e político, desde o GIP ao menos. ${ }^{92}$ Maio de 68 foi um momento de prise de la parole. ${ }^{93}$ Mas creio que há algo mais profundo aí sobre o que náo se insistiu. Não se tratava de uma simples crítica do porta-voz ou da figura do crítico social autorizado.

\footnotetext{
${ }^{92}$ Assinalemos de passagem que o seminário que deu origem ao estudo sobre o dossiê de Pierre Rivière se iniciou no período que coincide com a militância política de Foucault no GIP (Grupo de Informaçóes sobre as Prisóes). Em uma entrevista aos Cahiers du cinéma, de 1976, ele destaca o aspecto político desse programa editorial. KANÉ, Pierre [1976]. Entretien avec Michel Foucault, op. cit., p. 97-101, v. II [Texto no 180]. ${ }^{93}$ CERTEAU, Michel de. La prise de parole. Paris: Desclée de Brouwer, 1968.
} 
"ISSO NÃO É UM LIVRO DE HISTÓRIA": MiChEL FOUCAUlT E A PUBLICAÇÁO DE DOCUMENTOS DE ARQUIVOS

\section{Marlon Salomon}

Não se tratava tampouco de simplesmente dar voz aos criminosos e presos que até então não falavam. Creio que o que realmente estava em jogo aí era mostrar que havia um pensamento na fala dos que passavam a falar por si mesmos. Em 1982, em rara entrevista concedida após a publicação de Le désordre de familles, Foucault afirmava sobre o que os mobilizava, ao publicar documentos de arquivo em livro: "O que nos interessa é a história do pensamento. Não acreditamos que haja, de um lado, a análise dos comportamentos, de outro, a história das ideias; para nós, há pensamento em todos os lugares." ${ }^{44}$ Daí que não fosse preciso comentar, explicar essas falas, mas criar um espaço em que elas pudessem ser expostas. Os prisioneiros possuem uma teoria das prisóes que tem o mesmo estatuto daquela dos juristas. Os operários não precisaram ler os teóricos do Partido Comunista para saber que são explorados. Isso nos permite compreender os vetores não apenas teóricos da publicação de textos obscuros, desconhecidos, feita por Foucault. As implicaçóes filosóficas e historiográficas me parecem claras: tratava-se de pôr em questão essa ordem simbólica dividida entre lugares científicos e não científicos de enunciação, suas classificações e a hierarquia aí pressuposta entre o discurso que explica e o que precisa ser explicado, entre a luz do saber e as sombras da ignorância.

Mas esse projeto arquivístico-editorial não se explica apenas por questóes conjunturais, pois vai de encontro a um dos principais dogmas do pensamento histórico do século XX, segundo o qual os documentos e as falas que eles comportam, por si só, não dizem nada. Não seria demasiado recordar que, desde o século XIX, a descoberta e a publicação dos velhos papéis da história constituíam-se como parte importante do métier do historiador. Essa prática foi duramente criticada pelos modernos promotores da história, que a consideravam uma forma empobrecedora de empirismo. Sabemos como, do lado dos Annales, tratava-se não mais de deixar os documentos falar, mas, como queria Marc Bloch, "de fazê-los falar" 95 ou, como escrevia Lucien Febvre, de "fazer falar as coisas mudas, fazê-las dizer o que não dizem por si próprias sobre os homens, sobre as sociedades que as produziram". ${ }^{96}$

Mas essa crítica não se reduzia aos historiadores e era partilhada de modo abrangente entre os renovadores do saber da primeira metade do século XX. Do lado da história da filosofia, ela também encontrava eco. Em 1932, Ernst Cassirer criticava inflexivelmente o conceito "um tanto estreito e rígido" de conhecimento histórico de Fustel de Coulanges. Para ele, o autor de $A$ cidade antiga não pretendia apenas circunscrever o trabalho do historiador

\footnotetext{
${ }_{94}$ "Ce qui nous interesse, c'est l'histoire de la pensée. Nous ne croyons pas qu'il y ait, d'une part, l'analyse des compertements, d'autre part, l'histoire des idées; pour nous, il y a de la pensée partout." FOUCAULT, Michel; FARGE, Arlette [1982]. L'âge d'or de la lettre de cachet. In: FOUCAULT, Michel. Dits et écrits, op. cit., p. 1170, v. II [Texto no 322].

${ }^{95}$ BLOCH, Marc [1942]. Apologie pour l'histoire ou métier d'historien. In: BLOCH, Marc. L'histoire, La Guerre, La Résistance. Ed. crítica estabelecida por A. Becker e E. Bloch. Paris: Gallimard, 2006, p. 912.

96 "Faire parler les choses muettes, leur faire dire ce qu'elles ne disent pas d'elles-mêmes sur les hommes, sur les sociétés que les ont produites". FEBVRE, Lucien [1949]. Vers une autre histoire. In: FEBVRE, Lucien. Vivre l'histoire. Ed. crítica estabelecida por Brigitte Mazon. Paris: Laffont/A. Colin, 2009, p. 365.
} 
“ISSO NÃo É UM LIVRO DE HISTÓRIA": Michel FouCAUlt E A PUBLICAÇÃO DE DOCUMENTOS DE ARQUIVOS

\section{Marlon Salomon}

ao manejo de documentos, mas também reduzi-lo a eles. Para Cassirer, isso se observava em sua exigência de que o historiador não deveria falar em sua escrita, mas deixar que os textos falassem. Mas "os textos por si mesmos não dizem nada enquanto que o trabalho do historiador não os faça falar". Daí a necessidade de mobilizar "uma arte especial de interpretação, uma hermenêutica histórica" para "iluminar essa escuridão" 97 que é própria a esses textos. Lucien Febvre, que não poupava, nessa mesma época, críticas à história filosófica de Cassirer, subscreveria sem ressalvas esse princípio metodológico - e as críticas a Fustel - segundo o qual os documentos por si só nada dizem. E a expressão utilizada por Cassirer ou que Bloch e Febvre empregavam em mais de um lugar é bastante sintomática: é preciso "fazê-los falar" e não deixá-los falar por si mesmos. Era aí que a moderna École des Annales, para embaraço de um de seus fundadores, encontrava-se com a aparentemente distante Marburger Schule.

Em seu projeto de publicação de materiais de arquivo, Foucault parecia, numa primeira olhadela, reduzir novamente o trabalho historiográfico ao manejo e à publicação de documentos. Todavia, é preciso recordar que em 1969, às vésperas de lançar-se à publicação desses documentos, ele considerava que o estudo arqueológico do saber, na esteira de uma "mutação" que havia então alterado a posição da história acerca do documento, implicava um novo estatuto da noção de documento: não se tratava mais de "reconstituir, a partir do que dizem estes documentos — às vezes com meias palavras — , o passado de onde emanam e que se dilui, agora, bem diante deles". Tratava-se não mais de "interpretá-lo", de "determinar se diz a verdade" ou "seu valor expressivo", mas de "trabalhá-lo no interior e elaborá-lo". Era a partir daí que ele evocava o famoso par documento/monumento.

Digamos, para resumir, que a história, em sua forma tradicional, se dispunha a "memorizar" os "monumentos" do passado, transformá-los em "documentos" e fazer falarem estes rastros que, por si mesmos, raramente são verbais, ou que dizem em silêncio coisa diversa do que dizem; em nossos dias, a história é o que transforma os "documentos" em "monumentos". 98

\footnotetext{
${ }^{97}$ Cito-o a partir da tradução norte-americana. "His [Coulanges] standard was that the historiographer himself should not be heard but that the texts alone should speak. Yet in themselves the texts say nothing until they are made to speak through the labors of the historian. They are not only incomplete but in many, if not in most, cases obscure or contradictory. To lighten this darkness and remove these contradictions a special art of interpretation is needed, a historical "hermeneutics", which becomes more difficult the further removed is the object with which it deals." CASSIRER, Ernst. The problem of knowledge. Philosophy, Science, and History since Hegel. Tradução de W. Woglom e Ch. Hendel. New Haven: Yale University Press, 1950, p. 323. [CASSIRER, Ernst [1932]. Das Erkenntnisproblem in der Philosophie und Wissenschaft der neueren Zeit. Von Hegels Tod bis zur Gegenwart. Hildesheim/Zurique/Nova York: Georg Olms, 1991, v. IV, p. 326. Tradução francesa: CASSIRER, Ernst. Le problème de la connaissance dans la philosophie et la science des temps modernes. De la mort de Hegel aux temps présents. Paris: Cerf, 1995. v. IV, p. 408].

${ }^{98}$ FOUCAULT, Michel [1969]. A arqueologia do saber, op. cit., p. 8.
} 
"ISSO NÂO É UM LIVRO DE HISTÓRIA": MICHEL FOUCAULT E A PUBLICAÇÁO DE DOCUMENTOS DE ARQUIVOS

\section{Marlon Salomon}

Isso permite pensar que Foucault não apenas toma distância da concepção empirista de documento, aquela do século XIX, mas também dessa concepção hermenêutico-romântica em que se fundou o moderno pensamento histórico no século XX: não se trata de memorizá-los, fazê-los falar o que neles não fala ou reconstruir as referências externas a ele, mas de descrevê-los em si mesmos. Por isso, a partir de então e ao contrário do que tradicionalmente se passou, era a história que se voltava "para a arqueologia — para a descrição intrínseca do monumento".99

Se em suas arqueologias do saber, em vez de interpretar os documentos e fazê-los dizer o que não dizem, Foucault transformava os documentos em monumentos e os descrevia em seus próprios contornos e materialidade, em seu projeto editorial-arquivístico ele explorava outro aspecto da arqueologia sobre o qual não se deteve em 1969. Pois em uma arqueologia há ao menos uma sequência de dois gestos. Num primeiro momento, um arqueólogo remove um artefato de um sítio; e ao fazê-lo, ele destrói o vínculo ou a relação "natural” e evidente que havia entre eles (um artefato e um lugar). Num segundo momento, ele o apresenta num espaço de exposição totalmente distinto e desnaturalizado. Foucault não apenas desnaturalizava ou destruía uma evidência ao remover peças de um sítio, ao desarticular a relação supostamente evidente entre um artefato cultural e o lugar necessário de sua existência (entre a fala de um criminoso e sua classificação na instituição psiquiátrica, entre um texto e a ordem dos livros etc.), mas buscava em seguida produzir a cena em que elas poderiam ser exibidas. Era exatamente essa remoção e a exposição desses "monumentos" o que aí estava jogo. Foucault não apenas destruía as classificaçóes e hierarquias em que essas falas foram inscritas ao extraí-las de seus "sítios" naturais (um processo judiciário, uma revista de psiquiatria etc.), mas construía a cena em que poderiam ser expostas. E o que essa exposição apresentava era o pensamento onde até então só se identificava mudez: essa papelada dá a ler o que o camponês "de cerca de 20 anos que dizia mal saber ler e escrever"100 (e que era considerado em seu vilarejo como um idiota) pensa e mesmo o que ele diz sobre o que ele pensa. Foi como um arqueólogo, provido de uma nova compreensão do documento, que ele formatou esse projeto.

\section{Referências bibliográficas}

ANÔNIMO. My secret life. Récits de La vie sexuelle d'um anglais de l'époque victorienne [extraits]. Paris: Les Formes du Secret, 1977.

BLOCH, Marc [1942]. Apologie pour l'histoire ou métier d'historien. In: BLOCH, Marc. L'histoire, La Guerre, La Résistance. Ed. crítica estabelecida por A. Becker e E. Bloch. Paris: Gallimard, 2006, p. 843-985.

\footnotetext{
${ }^{99}$ Idem.

${ }^{100}$ FOUCAULT, Michel [1973]. Eu, Pierre Rivière, que degolei minha mãe, minha irmã e meu irmão..., op. cit., p. 10.
} 
CASSIRER, Ernst [1932]. Das Erkenntnisproblem in der Philosophie und Wissenschaft der neuren Zeit. Von Hegels Tod bis zur Gegenwart. Hildesheim/Zurique/Nova York: Georg Olms, 1991, v. IV.

. The problem of knowledge. Philosophy, Science, and History since Hegel. Tradução de W. Woglom e Ch. Hendel. New Haven: Yale University Press, 1950.

CERTEAU, Michel de. La prise de parole. Paris: Desclée de Brouwer, 1968.

DEFERT, Daniel; EWALD, François. Nota explicativa do texto "La vie des hommes infâmes”. In: FOUCAULT, Michel [1977]. La vie des hommes infâmes. Dits et écrits. 2. ed. Paris: Gallimard, 2001, p. 237-253, v. II [Texto $\mathrm{n}^{-}$198].

ERIBON, Didier. Michel Foucault e seus contemporâneos. Rio de Janeiro: Zahar, 1996.

FARGE, Arlette. Vivre dans la rue à Paris au XVIII siècle. Paris: Gallimard/Julliard, 1979.

FEBVRE, Lucien [1949]. Vers une autre histoire. In: Vivre l'histoire. Ed. crítica estabelecida por Brigitte Mazon. Paris: Laffont/A. Colin, 2009.

FOUCAULT, Michel [1969]. A arqueologia do saber. 2. ed. Rio de Janeiro: Forense Universitária, 1986.

. A ordem do discurso. Tradução de Laura Sampaio. 2. ed. São Paulo: Loyola, 1996.

. A vida dos homens infames. Ditos e escritos $I V$ - Estratégias, poder-saber. 2. ed. Rio de Janeiro: Forense, 2006, p. 203-222.

. A vida dos homens infames. In: . O que é um autor? 2. ed. Lisboa: Passagens, 1992, p. 89-128.

. Des travaux. In: Dits et écrits. 2. ed. Paris: Gallimard, 2001, p. 1185-1186, v. II [Texto $\mathrm{n}^{\mathrm{o}}$ 324].

[1976]. Entretien avec Michel Foucault. In: - Dits et écrits. 2. ed. Paris: Gallimard, 2001, p. 97-101, v. II [Texto no 180].

[1973]. Eu, Pierre Rivière, que degolei minha mãe, minha irmã e meu irmão... Tradução de Denise Lezan de Almeida. 2. ed. Rio de Janeiro: Graal, 2013.

(Org.). Herculine Barbin dite Alexina B. Paris: Gallimard, 1978.

. Histoire de la folie à l'âge classique. 2. ed. Paris: Gallimard, 1972.

. História da loucura na Idade Clássica. 5. ed. São Paulo: Perspectiva, 1997.

[1976]. História da sexualidade. A vontade de saber. Tradução de Maria Thereza Albuquerque e J. A. Guilhon Albuquerque. 18. ed. Rio de Janeiro: Graal, 2007.

[1977]. La vie des hommes infâmes. In: . Dits etécrits. 2. ed. Paris: Gallimard, 2001, p. 237-253, v. II [Texto $\mathrm{n}^{\mathrm{o}}$ 198].

[1984]. Le style de l'histoire. In: - Dits et écrits. 2. ed. Paris: Gallimard, 2001, p. 1468-1474, v. II [Texto no 348]. 
[1980]. Le vrai sexe. In: . Dits et écrits. 2. ed. Paris: Gallimard, 2001, p. 934942, v. II [Texto no 287].

[1976]. L’Occident et la vérité du sexe. In: - Dits et écrits. 2. ed. Paris: Gallimard, 2001, p. 101-106, v. II [Texto no 181]. . Surveiller et punir. Naissance de la prison. Paris: Gallimard, 1975.

. Vigiar e punir. História da violência nas prisóes. Tradução de Raquel Ramalhete. 9. ed. Petrópolis: Vozes, 1991.

FOUCAULT, Michel; DELEUZE, Gilles [1967]. Introduction générale. In: FOUCAULT, Michel. Dits et écrits. 2. ed. Paris: Gallimard, 2001, p. 589-592, v. I [Texto no 45].

FOUCAULT, Michel; FARGE, Arlette [1982]. L'âge d'or de la lettre de cachet. In: FOCAULT, Michel. Dits et écrits. 2. ed. Paris: Gallimard, 2001, p. 1170-1171, v. II [Texto $\mathrm{n}^{\circ}$ 322].

. Le désordre des familles. Lettres de cachet des Archives de la Bastille. Paris: Gallimard/ Julliard, 1982.

FURET, François [1974]. O quantitativo em história. In: LE GOFF, Jacques; NORA, Pierre. História: novos problemas. Tradução de Theo Santiago. 4. ed. Rio de Janeiro: Francisco Alves, 1995.

KANÉ, Pierre [1976]. Entretien avec Michel Foucault. In: FOCAULT, Michel. Dits et écrits. 2. ed. Paris: Gallimard, 2001, p. 97-101, v. II [Texto no 180].

LE GOFF, Jacques [1974]. As mentalidades: uma história ambígua. In: LE GOFF, Jacques; NORA, Pierre. História: novas abordagens. 4. ed. Tradução de Terezinha Marinho. Rio de Janeiro: Francisco Alves, 1995.

MACHADO, Roberto. Foucault, a filosofia e a literatura. Rio de Janeiro: Zahar, 2000.

RANCIÈRE, Jacques. Les noms de l'histoire: Essai de poétique du savoir. Paris: Seuil, 1992. VIDAL, Laurent. Arlette Farge, le parcours d'une historienne. Entretien avec Laurent Vidal. Genèses, 2002, no 48, p. 115-135. 